\title{
Religion and ideology
}

\author{
By JAN HJ $A ̈ R P E$
}

\section{Mu ammar al-Kadhdhāfî, Islam and the "Third International Theory"}

\section{Introduction}

In both ancient and modern Islam we find examples of institutionalization of an enthusiastic or charismatic religious movement, and we can study the processes leading to such a transformation from different points of view. Obvious and striking examples are to be found in the development of the Sufi orders, even in modern times. The reader is referred to M. Gilsenan's sociological study in the 1960's of the Hamidiya-Shadhiliya in Egypt (the founder of the order died in 1939) ${ }^{1}$, where the enthusiastic ecstatic movement centered around Shaikh Salama grew into a strict organization, with written rules and special rituals.

There is another form of institutionalization, also with good examples to be found in the World of Islam, namely the application of religion in political action and its transformation, in part, to a political ideology. We can demonstrate the process already in the development of Islam in the lifetime of Muhammad. The Quran reflects the changes in conditions and activities, the development from the passionate poetry of the revelations of the Prophet of Doom in Mecca to the practical legislation envisaged by the political genius in Medina, all of which were relevant to the needs of the growing community $(u m m a)^{2}$ in its struggle against enemies within and without. The difference should not be exaggerated, however ${ }^{3}$.

As an inheritance from the beginning of the Islamic umma we find the

${ }^{1}$ Cf. Gilsenan, $35 \mathrm{ff}$.

${ }^{2}$ As to the character of the umma, cf. Watt, 1956, $238 \mathrm{ff}$.

${ }^{3}$ For the development of Muhammad's message and its interrelation with the social and political changes, cf. Watt, 1961, $43 \mathrm{ff}$, especially $57 \mathrm{f}$. 
close connection between politics and religion, between Islam and the Islamic state, throughout the history of Islam, where the profane, the secular, is non-existent, where the rule of the state is a theological question, and where the quietism of the Sufis is a political problem. Every ecstatic religious movement in the World of Islam acquires political implications sooner or later. In modern times we find in the Islamic reform movements the firm intention to translate "Islamic principles" into political action and political institutions, an intention often combined with a far-reaching reinterpretation of the Quran and of the Tradition, and with an explicit deprecation of the "classical" islamic attitudes".

The modern state of Saudi Arabia constitutes an example of the gradual institutionalization of an enthusiastic and militant movement, the first significant reform movement, Wahhabism ${ }^{5}$, not only in its foundation but also in its development during the 1960 's and $70^{\prime} \mathrm{s}$. In his religious education the late King Faișal was the pupil of his maternal grandfather, himself a descendant of Ibn 'Abd al-Wahhāb. The domestic and foreign policy of the profoundly pious King Faișal was an application of his religious principles. We may note that the doctrines of Wahhabism are an important factor in the development of the complexity which is modern Islam.

I have chosen another example for this study, the Libyan Arab Republic (L.A.R.) and its leader since the revolution of September 1st 1969, Mu'ammar al-Kadhdhāfi. Here we find a reinterpretation of Islam and an explicit attempt to make this form of Islam the basis of a political ideology, the "Third International Theory". L.A.R. claims to be the model state, the Utopia, of the practical application of this ideology, in its institutions and in its political actions.

When the Libyan monarchy was overthrown in the coup d'état of September 1 st 1969 , the consequences were not only constitutional changes ${ }^{6}$ but a totally new policy, a policy which has been regarded as surprising and abstruse. al-Kadhdhāfi characterized the process of changes as a "cultural revolution", and the world outside noticed at least two features thereof: the application of quranic precepts in the criminal courts and the eagerness

\footnotetext{
${ }^{4}$ Cf. Delanoue $1068 \mathrm{ff}$, Goldziher $416 \mathrm{ff}$, Ali $625 \mathrm{f}$.

${ }^{5}$ For the Wahhābī movement and the hanbalì conception of religion and state, cf. Laoust, $1971 a, 677 \mathrm{ff}$, and $1971 b, 951 \mathrm{ff}$.

${ }^{6}$ The L.A.R. constitutional declaration (2. Shawwāl 1389=11th of December 1969), cf. Revolution, $1974 a, 3 \mathrm{f}$.
} 
to establish Arabic as an international language. The transformation in the domestic policy is also called a "popular revolution" and its goal appears to be an almost corporativistic society". al-Kadhdhăfi's speech at Zwara on April 16th 1973 is regarded as the beginning of the "popular revolution". The function of the "direct democrazy" and the political institutions in the L.A.R. falls outside the scope of this study, and I refer to H. Habib's book on Libyan politics ${ }^{8}$. I intend to discuss here the connection between religion and ideology, the way in which Islam as a religion is applied, reinterpreted and transformed into a political ideology, supplying the principles of Libyan policy, the "Third International Theory".

\section{Sources}

The main sources of the study were propaganda and information books and booklets issued by the Libyan Ministry of Information and Culture, speeches and writings by $\mathrm{Mu}^{c}$ ammar al-Kadhdhāfi himself, and some collections of newspaper interviews with him.

I give a detailed list of those quoted in the study:

\section{A. Propaganda and Information books and booklets issued by the Libyan Ministry of Information and Culture:}

The Revolution of 1st September, the fourth Anniversary,

Benghazi, 1973.

[Abbrev.: Revolution 1973]

The Popular Revolution, Fundamentals \& Objectives,

Tripoli, January 1974.

[Revolution $1974 b$ ]

La Revolution en Marche,

Tripoli (?), September 1974.

[Revolution 1974c]

1st September Revolution Achievements, 5th Anniversary,

Tripoli, 1974.

[Revolution 1974a]

\footnotetext{
7 "The popular revolution" is described in al-Kadhdhāfi, 1974, $113 \mathrm{ff}$, cf. the booklet Revolution, $1974 b, 1 \mathrm{ff}$.

${ }^{8}$ Cf. Habib $1 \mathrm{ff}$, cf. Human $31 \mathrm{ff}$, and, as for al-Kadhdhäfi' s view on other constitutions, al-Kadhdhăfî, $1976 b, 1 \mathrm{ff}$.
} 
The Human March in the Libyian Arab Republic,

Rome, 1976; Masīrat al-insān fî-l-djumhūrīyat al-`arabīyat al-lỉbīya.

[Human]

at-Taharruk as-siyāsī li-1-djumhūrīyat al-'arabīyat al-lībīya fĩ ittidjāh 'așr aldjamāhīr,

Tripoli, 1976

[at-taharruk]

B. Speeches and writings by Mu'ammar al-Kadhdhāfī:

Allocution du Président Moammer Gadhafi et les responsables de l'information et des cadres de l'USA au Caire ... Portant sur la Religion, le Nationalisme et les problèmes s'y référant 5 Moharram 1393 H, 8 Février 1973,

Tripoli, s.a.

[al-Kadhdhāfi s.a.a]

Discours du frer (sic!) président du conseil du commamdement (sic!) de la revolution tenu au complexe sportif « Gueddafi » à Lahore 25 Février 1974,

Tripoli, s.a.

[al-Ḳadhdhäfi s.a.b]

Discours du colonel Moamar Gadhafi ... en Tunisie,

Tripoli, s.a.

[al-Kadhdhāfi s.a.c]

Mu'ammar al-Kadhdhāfí, al-Kitäb al-Akhḍar, al-faṣl al-awwal,

Tripoli (?), 1976.

[al-Kadhdhäfi 1976b]

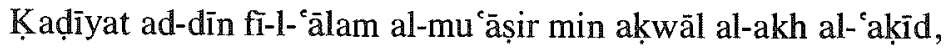

Tripoli (?), 1976.

[al-Kadhdhāfi 1976a]

To this we may add the ex tempore speech by al-Kadhdhäfi on religion and ideology at the Muslim-Christian Dialogue seminar at Tripoli, the 2nd of February $1976^{9}$.

[al-Kadhdhäfi 1976c]

\section{Collections of interviews with}

Mu'ammar al-Kadhdhāfí from newspapers and periodicals: Discourses by Mu'ammar el-Qathafi, Chairman of R.C.C., published in the Arab and International Press,

S.1., 1975.

[al-Kadhdhäfi 1975]

${ }^{9}$ I had the opportunity to listen to the speech at Tripoli and to observe al-Kadhdhāfi as an orator, cf. Hjärpe $93 \mathrm{f}$. 
The Paris Symposium, the intellectual meeting between the East and the West $^{10}$,

Beirut, s.a.

[al-Ķadhdhäfĩ s.a.d]

Thus spoke Colonel Moammar Kazzafi,

Beirut, 1974

[al-Kadhdhäfi 1974]

\section{Mu ammar al-Kadhdhäfi on history (philosophy of history)}

Mu'ammar al-Kadhdhāfi was born in 1942, into al-Kadhādhifa, a nomadic tribe claiming descent from the Prophet Muhammad ${ }^{11}$, and his parents are still bedouin. Thus his ancestry befits an Arab nationalist, in that he is both bedouin and sharif. A characteristic feature of his outlook is the appreciation of the moral values of the simple life of the bedouin and a certain contempt for the decadence of the coastal cities ${ }^{12}$. In one of the interviews he tells us about his childhood's world of ideas ${ }^{13}$, with chivalry (muruwwa) as the leitmotif and 'Alī ibn Abĩ Tâlib as the great hero ${ }^{14}$.

He learned to read at home from the Quran, but his formal school education began only in 1954: he attended military school in Libya in 1963-66 and in England in 1966. In 1967 he began to study history at university ${ }^{15}$. He was of course already politically active at that time.

There is a close connection between al-Kadhdhāfî's "philosophy of history", his view of religion and his political behaviour.

al-Kadhdhăfi declares that the main factors in history, the moving or driving forces, are religion and nationalism,

"conflicts between religions, as well as between nationalisms, form history" 16 .

"The two principal factors in the formation of our history, the history of mankind, are nationalism and religion." 17

\footnotetext{
10 The symposium was at Plaza Hotel in Paris, the 24th of November 1973.

${ }^{11}$ Cf. al-Kadhdhāfi, 1974, 24.

12 We may compare this with the philosophy of Ibn Khaldūn.

${ }^{13}$ Cf. al-Kadhdhāfi, 1974, 26 and 35.

${ }^{14}$ Cf. ib. 25.

${ }^{15}$ al-Kadhdhãfi tells about his studies in the first interview in ib. especially $26 \mathrm{ff}$.

${ }^{16}$ Human 47, cf. al-Kadhdhāfī, 1974, 65 f, al-Kadhdhäfi, s.a.a, 5 ff, and Revolution, 1974 a, 10. 17 al-Kadhdhāfì, s.a.d, 16.
} 
All other factors are considered secondary to these two ${ }^{18}$. The thesis is of course mainly directed against the Marxist interpretation of history. I quote:

"When I read history, I do not find that the movement of history is determined by an economic factor disguised by nationalism or veiled in religion. History very clearly shows that its movement is a national and religious conflict." 19

During the "Paris Symposium" a question was asked about the Atatürk revolution in Turkey, indicating that it contradicted al-Kadhdhāfì's view on history. As an example of his analysis I quote his answer:

"The Turkish nation's movement before Atatürk was a religious one which influenced world history. Atatürk came at a time when the national factor was starting to play its role. So, his movement was a nationalist one which consequently affected the nation's or the area's destiny. The religious idea may appear again strongly in Turkey, and Turkey's history may enter the religious stage. This stage is now evident. I believe there are signs and impulses for returning to Islam and revolutionizing The Turkish condition in accordance with Islam, and consequently for entering the stage of religious interaction. Thus, history is witnessing a movement between religion and nationalism. This is my analysis to the Atatürk movement. It is a nationalist movement and an assertion to my interpretation of history which is moved by religion and nationalism.

Europe went through those stages in a religious period, and it was divided and fought for religion. It also went through a nationalist period, and it was divided and fought for nationalism. Those stages alternate continually. Nationalism and religion will once again play their role in the Soviet Union, and this conflict enters into the determinateness of history. That is why the Soviet Union tries to remove the religious and nationalist factors to avoid this certainty or determinateness." 20

He finds many examples in modern history. The division of India into Pakistan and the Indian Republic had religious overtones, the partition of Pakistan and the creation of Bangladesh was caused by antagonism between

${ }^{18}$ Cf. ib. $16 \mathrm{f}$ and $62 \mathrm{f}$.

19 Ib. 79 .

${ }^{20}$ Ib. 57. 
different nationalities ${ }^{21}$, the civil war in Yemen was caused by religionone group is called "progressive", the other "reactionary", but the true ground of the conflict is the old animosity between Zaydites and Shăfi ites ${ }^{22}$, and

"is the existence of the Israelis in Palestine due to any economic reason? Is there oil? Is there gold? This is again a religious, national conflict ... Now, experts and pilots leave the nice life in other countries and come for religious and national purposes and reasons to fight the Arabs" 23 .

Since he regards Palestine as belonging to the Arabs, he concludes that

"[...] the conflict between Israel and us is natural and is one of the laws of nature" 24 .

\section{4. "The Third International Theory"}

"Since reading history has shown us that nationalism and religion are the factors that shape history, we must take them into account and respect nationalism and hallow religion." 25

The practical consequence of al-Kadhdhäfi's interpretation of history is that he makes nationalism and religion the ultimate norms for every political decision. Wars and suffering will disappear if we can solve the problem of conflict between religions and nationalisms ${ }^{26}$. In Libya's foreign policy this involves support for several nationalist movements (e.g. the I.R.A.) ${ }^{27}$ and for organisations aiming at the practical application of religion, while in her domestic policy it means the application of "Arabism" and the Islamic Sharīa. The behaviour which results has its intellectual counterpart in a political programme or ideology, called the "Third International Theory" 28 . It is named the "Third" Theory as it is supposed to supersede both the

${ }^{21}$ Cf. al-Ḳadhdhāfi, s.a.a, 8, al-Ḳadhdhăfī, s.a.d, $79 \mathrm{f}$.

22 Cf. al-Kadhdhãfi, s.a. $a, 9$.

${ }^{23}$ al-Kadhdhāfi, s.a.d, 80, cf. Revolution, 1974a, 18.

24 al-Kadhdhäfĩ, 1975, 46.

25 al-Kadhdhãfi, s.a.d, 16.

${ }^{26}$ Cf. Human 48.

${ }^{27}$ Cf. Revolution, 1974 a, 20, al-Ḳadhdhāfi, s.a.c, 31, and al-Kadhdhāfî, 1974, 128 f, 157.

${ }^{28}$ Cf. al-Kadhdhāfī, 1976b, $1 \mathrm{ff}$. A short description of the "Theory" is given in the booklet Revolution, 1974c, $21 \mathrm{ff}$, and in Revolution, 1973, 231 and $239 \mathrm{ff}$, and in Revolution, 1974a, $9 \mathrm{ff}$, al-Kadhdhãfi, 1975, $133 \mathrm{ff}$. 
liberalism-capitalism of the West and the Marxist communism of the East. The Libyan nation

"found the Western system based on exploitation, by individuals of the community where the rule says 'Survival of the strongest', which has reduced society to a collection of broken families, torn apart by crime, vice and degeneration of all values. Our nation also studied the eastern system based on exploitation of individuals by a party in the name of the dictatorship of class, where human beings have no freedom and are subject to absolute materialist ideas which contradict with human values" ${ }^{29}$.

I do not intend to expound the details of the "Third Theory", but we shall consider the way in which the "Theory" is connected with Islam. One declares explicitly that the "Third Theory" is based on religion and nationalism $^{30}$. It is obvious, however, that the concept of religion and what it implies is Islamic in essence.

What is the role of religion (Islam) in the "Third International Theory"? The following theological concept plays a considerable role in the formulations of the propaganda booklets on the "Third Theory", and they are without doubt fundamental for Mu ammar al-Kadhdhāfĩ himself:

1. The oneness of God who governs the Universe ${ }^{31}$.

2. "The Heavenly Books" (Quran, Bible [=Indjīl, The Gospel], Torah), as the sources for "unequivocal answers". The Quran is the absolute norm, the infallible authority, while human philosophies are subject to error.

3. The creation of Man and Universe by God, and Man as God's khaliffa on earth ${ }^{32}$

(cf. Sura 2: 30/28).

4. The resurrection and the Day of Judgement and immortality. The faith in these constitutes religion as the source of moral obligation ${ }^{33}$.

5. The eternity of struggle between right and wrong and the inevitability of God's predestination ${ }^{34}$.

\footnotetext{
${ }^{29}$ Revolution, $1974 a$, 9, cf. al-Kadhdhäfî, s.a.d, $84 \mathrm{f}$.

${ }^{30}$ Cf. al-Kadhdhāfī, 1974, 124, cf. 49.

${ }^{31}$ Cf. Revolution, 1974a, 10, Human 42.

${ }^{32}$ Cf. al-Kadhdhāfī, 1976a, 9 f.

${ }^{33}$ Cf: ib. 48, cf. al-Kadhdhāfi, 1975, $122 \mathrm{f}$.

${ }^{34}$ Cf. Revolution 1974 a, 10, Human 42.
} 
Point 4 is the most important. I quote:

"The Third International Theory emphasizes moral obligation as an important element in a civilised community, in personal dealings and international relations. Such a moral obligation, in view of the Third International Theory, cannot be achieved without faith. Religion creates a moral deterrent [sic!] in individuals and communities. Such a moral obligation 'forces good work and prevents evil'."35 (cf. Sura 3: 104/100, 110/106).

It is often emphasized that Man needs religion ${ }^{36}$.

As for the practical application it is explicitly stated that the social relations between individuals and between individual, family and state shall be in accordance with the Islamic Shari $\mathrm{a}^{-6}$.

To "respect nationalism and hallow religion", means, in the case of Libya, to stress the Arabism and to apply Islamic morals. This process is called a "cultural revolution" and includes an ardent endeavour to eradicate "corrupted and foreign ideas and concepts" and prevent the infiltration of such ideas from both East and West ${ }^{38}$. We read in one of the booklets:

"Books which contained such corrupt thoughts had to be burned because their contents opposed our revolutionary trend, and contradicted our religion and noble Arab heritage." 39

And in another:

"The Arab Libyan has realized that it is necessary to liquidate colonialism and its aftermath in order to reconstruct his country. Liquors were banned. Bars and night clubs were closed. Measures were taken to cleanse the Arab Islamic environment of imported malpractices and debauchery. All laws have been reviewed and rewritten in accordance with the Islamic Law (Sharia). This does not mean that the Arab Libyan rejects modern trend of thought. He is just sifting and filtering them to choose what suits his heritage and needs." 40

\footnotetext{
${ }^{35}$ Revolution $1974 a$, 11, cf. Séminaire $\$ 3$.

${ }^{36}$ Cf. al-Kadhdhăfi, s.a. $a, 5$.

${ }^{37}$ Cf. Human 49, cf. Revolution, 1974a, 11.

${ }^{38}$ Cf. Revolution, 1974b, 20, Revolution, 1974a, 12, Human 31.

${ }^{39}$ Revolution, 1974b, 23.

${ }^{40}$ Human 87, cf. Revolution, $1974 a, 13$.
} 
The Arabism of Mu'ammar al-Kadhdhāfĩ is also reflected in his own and the other leaders' social behaviour ${ }^{41}$. We can also mention one example of his extreme nationalism: Libya does not celebrate the May 1st as a Workers' day, as al-Kadhdhāfi wants a special Arab national workers' day and not an international one ${ }^{42}$.

The "sectarianism" of Islam is a serious problem, as we know, in Lebanon, Syria, Iraq, if not in Libya, and al-Kadhdhāfî believes that this "sectarianism" will cease to exist if the principle of nationalism is applied ${ }^{43}$. The pride in Arab nationality includes pride in the history and cultures of all the Semitic peoples of antiquity; "Semitic" is often replaced by "Arab" so that the "Arabs" include the Accadians, the Phoenicians and Carthaginians etc. ${ }^{44}$. "Arabism", according to al-Kadhdhāfi, always implies work for Arab unity (shu'b arabi wāhid, "one Arab people"), and this is one of the most important points in his policy ${ }^{45}$, the unity of all Arabs, Muslims and Christians; the tendency to local nationalism, Egyptian, Iraqi or Palestinian, is a violation of this principle. I shall illustrate with a quotation from an interview. The journalist provokingly asks whether Mu'ammar al-Kadhdhāfi would like those Arab presidents who are afraid of Arab unity to be overthrown, and he answers:

"If this ensures the achievement of unity, why not?! The Arab Nation should unite whatever the sacrifices may be. Unity is the only solution. It is the only way out of this desperate situation." 46

The centre of the Arab Nation must be Egypt, Cairo being the capital of both Arabism and Islam ${ }^{47}$, and al-Kadhdhāfi's ideal of Arab unity and its confrontation with the policy of Egypt is one of the main factors in the complicated political pattern in the Arab world today. We may also notice that the dependence of the Libyan September 1st revolution on the "mother" revolution of July 23rd (1952) in Egypt and on the "LeaderTeacher" Nasser is often underlined in the speeches of al-Kadhdhāfi ${ }^{48}$.

${ }^{41}$ Cf. al-Kadhdhāfi, 1974, $47 \mathrm{f}$.

42 Cf. ib. $103 \mathrm{f}$.

${ }^{43} \mathrm{Cf}$. ib. $56 \mathrm{ff}$, cf. 49.

${ }^{44} \mathrm{Cf}$. the lecture of prof. Ismail al-Faruqi at the Dialogue seminar, Hjärpe $94 \mathrm{f}$.

${ }^{45}$ Cf. at-taharruk, $8 \mathrm{f}$.

46 al-Kadhdhăfi, 1974, 90.

${ }^{47}$ Cf. al-Kadhdhāfî, s.a. $a, 4 \mathrm{ff}$.

${ }^{48}$ Cf. Human $55 \mathrm{ff}$, Revolution, 1974a, 19, Revolution, 1973, 203f, al-Kadhdhāfi, 1974, 9, al-Kadhdhāfi, 1975, 129. 
The Libyian president emphasizes that political parties and factions have seriously harmed the Muslims, and therefore political parties ("factionalism"), are forbidden in Libya, regarded as treason and punishable with death ${ }^{49}$.

The "Third Theory" seeks to "hallow religion", and this is one reason why al-Kadhdhāfi opposes communism, and even speaks of a "Holy war" (djihād) against it ${ }^{50}$.

We read in one of the pamphlets:

"For the Moslem, religion is everything and he cannot be cordial to a communist at the expense of religion. How can a man feel confidence about a communist's moral standards when he does not believe in God?"51

In an interview in the Yugoslavian paper Zagreb (29th April 1974), Mu ammar al-Kadhdhăfĩ says of the Muslims in Yugoslavia:

"So long as Islam is respected and sanctified and left to grow so long in return the friendship and affection between Yugoslavia and ourselves develop progressively." 52

The quotation also illustrates the panislamistic principle in the application of the "Third Theory". Economic and political help is given to Muslims and to Islamic institutions all over the world ${ }^{53}$, and panislamism is sometimes designated as a "Holy war" 54 . The solidarity of all Muslims is especially accentuated outside the Arab world, e.g. in al-Ḳadhdhăfì's speech in Lahore (25th Febr. 1974) ${ }^{55}$.

\section{Islam reinterpreted and applied}

"We must differentiate between Islam and the ways it is practiced by Muslims." ${ }^{6} 6$

In this way Mu'ammar al-Kadhdhäfi expresses a thesis common to all the reform movements, namely the distinction between "true" Islam and Islam

\footnotetext{
${ }^{49}$ Cf. al-Kadhdhāfĩ, 1974, 92 f, cf. Human 31, and al-Kadhdhāfi, 1976 $b, 12$ ff.

${ }^{50}$ Cf. Revolution, 1973, 245, cf. 238f, and al-Kadhdhāfi, s.a.c, 38.

${ }^{51}$ Revolution, 1973, 245.

${ }^{52}$ al-Kadhdhāfi, 1975, 149.

${ }^{53}$ Cf. at-taharruk, $16 \mathrm{ff}$, Revolution, 1974 a, 23f, Human $63 \mathrm{ff}$.

${ }^{54}$ Cf. Revolution, $1974 a, 23$.

${ }^{55}$ Cf. al-Kadhdhāfi, s.a.b, e.g. 5 f, 9.

${ }^{56}$ al-Kadhdhāfí, s.a.d, 68.
} 
as an empirical historical and sociological phenomenon. The goal is to substitute at true Islam for the false one which has hitherto dominated ${ }^{57}$. He is especially anxious to emphasize that true Islam is in favour of modern science and technical and social progress ${ }^{58}$.

"If Islam ... [had been correctly] understood from the beginning it would have been a real scientific, technological revolution. Unfortunately, Islam was understood in a very simple ordinary manner, so simple that when electricity was discovered it was thought to be anti-religion. When the moon was explored there was wide-spread disapproval. This is a misunderstanding of Islam. Islam says that all things are created in pairs ... (cf. Sura 36:36). This is in line with the negative and positive and the northern and southern we know. Electricity, for example, consists of negative and positive poles." 59

Verses from the Quran are interpreted as supporting modern social principles, the verse "O mankind, we created you from a single pair of male and female" (Sura 49:13a) referring to equality of men and women, and "Verily the most honoured of you in the sight of God is he who is the most righteous of you" (Sura 49:13b) to racial and national equality-and so on ${ }^{60}$.

As for the application of Islam and Islamic principles today, al-Kadhdhāfi takes an important step: The binding norm is of course the Quran ${ }^{61}$, but the Quran without $t a f s i r$, without the traditional exegesis. He speaks explicitly of a "Sola scriptura" principle, because of the impossibility of distinguishing between true and falsified ahâdith (traditions) ${ }^{62}$. This principle will eliminate the problem of "sectarianism" in Islam according to the Libyan president ${ }^{63}$, and practical solutions will be found for the performance of religious duties $^{64}$, fasting, praying etc., in the conditions of the modern world. This belief presumes that the Quran is not ambiguous.

An important point in al-Kadhdhāfì's concept of religion is his distinction

\footnotetext{
57 Cf. al-Kadhdhăfí, s.a. c, 20.

${ }^{58}$ Cf. E.g. al-Kadhdhāfi, s.a.d, $68 \mathrm{f}$.

59 al-Kadhdhāfí, 1975, $122 \mathrm{f}$.

${ }^{60}$ Cf. al-Kadhdhāfî, s.a.d, $54 \mathrm{ff}$.

${ }^{61}$ Cf. e.g. Revolution, $1974 a, 11$.

${ }^{62}$ Cf. al-Kadhdhäfī, $1976 \mathrm{c}$.

63 Cf. al-Kadhdhāfi, 1974, 50 f.

${ }^{64} \mathrm{Cf}$. al-Ka adhdhāfi, 1975, $20 \mathrm{f}$.
} 
between the "divine" Islam and the "historical" Islam ${ }^{65}$-not to be confused with the distinction "true" and empirical Islam. The "divine" Islam, witnessed by the Quran, is the monotheism of Abraham, Moses, Jesus, Muhammad, and all the Prophets, while the "historical" Islam is the religion and revelation of Muhammad. The basis of the "Third Theory" is, according to al-Kadhdhäfi, to be found in the "divine" Islam, so that this Theory should also be adopted by Christians and Jews. But the Muslim believes in all the Prophets, and when the Christian (and the Jew) denies the prophethood of Muhammad there is a defect in his faith ${ }^{6}$. The old accusation that Jews and Christians manipulated the Scriptures is also mentioned, and al-Kadhdhäfi compares (and not without reason) the Gospels with the Islamic Hadith literature ${ }^{67}$. The conversion of atheists to "divine" Islam, to the worship of God alone, is regarded as a common interest for Christians and Muslims ${ }^{68}$.

"'Say: O People of the Book! Come to common terms as between us and you: That we worship none but God; that we associate no Partners with Him; that we erect not, from among ourselves lords and patrons other than God', says the Quran (Sura 3:64/57). By this we understand the worship of big powers, the worship of Lenin, and even the worship of Muhammad whom we consider only a Prophet $[\ldots]^{\prime \prime 69}$

One saying of al-Kadhdhāfi is very revealing: "Islam [.. .] is a secular religion". In this sentence we find the definition of the transformation of religion into a political ideology:

"[...] Islam itself is a secular religion: the Koran deals with the economic, social and political order, with war, peace, peacemaking, treatment of prisoners, personal conditions and laws, neighbourhood and interrelations of societies. In addition and above all, it regulates man's relationship with God. Originally, Islam is a secular religion, and therefore there is no secularism in Islam. If some Arab countries have spoken of secularism and

\footnotetext{
${ }^{65}$ Cf. al-Kadhdhäfi, s.a.a, $10 \mathrm{f}$ and $14 \mathrm{ff}$, al-Kadhdhäfi, 1974, $48 \mathrm{f}$, and Revolution, 1973, $240 \mathrm{f}$.

${ }^{66}$ Cf. al-Kadhdhāfi, s.a. $a, 12$ f, cf. al-Kadhdhāfi, 1974, 49.

${ }^{67}$ Cf. al-Kadhdhāfi, $1976 c$, cf. al-Kadhdhāfi, s.a.a, 11.

${ }^{68} \mathrm{Cf}$. al-Kadhdhãfi, s.a. $a, 22$.

${ }^{69}$ al-Kadhdhāfi, s.a.d, 86, cf. al-Ḳadhdhäfi, s.a. $a, 21$.
} 
declared their belief in it, this is attributable to a misunderstanding of Islam in the period of Islam's decline [...]

[Islam] regulates economic life for both the individual and society [...] It regulates defense of the individual and the state [ . . ] It regulates relations between nations. Islam has not disregarded any economic, political, military or social aspect: it has regulated them all $[\ldots]^{70}$

[...] Our state revives Islam [ . . . There is absolutely no contradiction between socialism and Islam. Actually, the more we revive Islam the more we will be emphasizing the basics of social justice which itself is socialism." 71

We may emphasize that by "socialism" al-Kadhdhâfi does not mean socialism in the western sense ${ }^{72}$, since for instance private ownership (if non-exploiting) is safeguarded, and inheritance regulated according to the Islamic Shari $\mathrm{a}^{73}$.

The work for the practical application-or institutionalization-of Islam in Libya is governed by the Higher Council for National Guidance, the first meeting of which took place on November 21st $1972^{74}$. The basis of national guidance is explicitly said to be Islam, but, as we can see from the following quotation, a reformed and reinterpreted Islam, in the tradition of the "modernists" from the first half of this century:

"We need to reoffer Islam as a complete philosophy and general framework governing the relationship of the citizen with God and society and as a general picture of life as it should be. This way the citizen is armed by a genuine understanding of Islam in its religious moral and spiritual values against falsehoods and materialism. There are many ways to achieve this including providing the citizen with spiritual and cultural needs as exemplified in the Holy Koran, Sunna and Moslem legacy in addition to the revival of Moslem spiritual and moral principles like the desire for jihad, the rejection of negative attitudes and dependence, seeking the means of power, work for the fostering of the family and the promulgation of Islam throughout the world and the reconsideration of legislation in force in the light of Moslem Sharī $a . " 75$

\footnotetext{
70 al-Kadhdhāfî, s.a.d, 66, cf. Revolution, $1974 b, 29 \mathrm{f}$.

${ }^{71}$ al-Kadhdhāfi, s.a. $d, 67$, cf. al-Kadhdhāfī, 1974, 54.

${ }^{72}$ Cf. Human 42, al-Kadhdhāfì, s.a.d, 21.

${ }^{73}$ Cf. Human 25.

${ }^{74}$ Cf. Revolution, 1973, $161 \mathrm{ff}$.

${ }^{75} \mathrm{Ib} .163 \mathrm{f}$.
} 
Islam is hallowed, acts against the precepts of religion are punished ${ }^{76}$, the Shari $a$ is applied ${ }^{77}$, national liberation movements are regarded as dithād and supported ${ }^{78}$, at international conferences Libya has demanded the suppression of drugs and strong drinks ${ }^{79}$ etc. The aim of the L.A.R. and its leader Mu ammar al-Kadhdhāfi is to create in Libya a "revolutionary example", a model for an Arab Islamic state ${ }^{80}$, the practical application of Islam in political and social life, an Islam regarded as a "secular religion".

\section{Bibliography}

Unprinted source

al-Kadhdhāfī, M., $1976 \mathrm{c}$, An ex tempore speech by Mu ammar al-Kadhdhäfi on religion and ideology at the Muslim-Christian Dialogue seminar at Tripoli, 2 February 1976. (Notes in the possession of the author.)

Printed sources and literature

Ali, A., 1975, Karämat 'Alì. EI 4.

Delanoue, G. 1971, al--Ikhwān al-Muslimūn. EI 3.

EI Encyclopaedia of Islam. Leiden \& London.

Gilsenan, M., 1973, Saint and Sufi in Modern Egypt. Oxford.

Goldziher, I. - Jomier, J., 1965, Djamāl al-dīn al-Afghānī. EI 2.

Habib, H., 1975, Politics and Government of Revolutionary Libya. Montreal.

Hjärpe, J., 1976, Det islamisk-kristna dialogseminariet i Tripoli, Libyen. Svensk missionstidskrift 2.

Human, 1976, The Human March in the Libyan Arab Republic [=Masirat al-insān fí al-djumhüriyyat al-ªrabiyyat al-libiyya]. Rome.

al-Kadhdhäfi, M., S.a.a, Allocution du Président Moammer Gadhafi et les responsables de l'information et des cadres de l'USA au Caire ... Portant sur la Religion, le Nationalisme et les problèmes s'y référant 5 Moharram 1393 H, 8 Février 1973. Tripoli.

- S.a.b. Discours du frer (sic!) président du conseil du commamdement (sic!) de la revolution tenu au complexe sprotif «Gueddafi » à Lahore 25 Février 1974. Tripoli.

- S.a.c, Discours du colonel Moamar Gadhafi ... en Tunisie. Tripoli.

- S.a.d, The Paris Symposium, the intellectual meeting between the East and the West. Beirut.

- 1974, Thus spoke Colonel Moammar Kazzafi. Beirut.

- 1975, Discourses by Mu'ammar el-Qathafi, Chairman of R.C.C. published in the Arab and International Press. S.1.

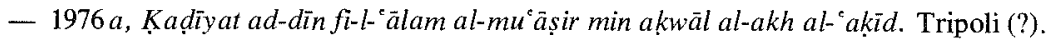

- 1976b, al-Kitāb al-Akhdar, al-faṣl al-awwal. Tripoli (?).

76 Cf. Revolution, $1974 b, 9$.

77 Cf. Revolution, $1974 a, 156$.

78 Cf. al-Kadhdhăfĩ, 1974, 36, Revolution, 1974a, 20.

${ }^{79}$ Cf. Revolution, $1974 a, 21$.

${ }^{80}$ Cf. ib. IV, al-Kadhdhăfi, 1975, $15 \mathrm{f}$ and 136, Revolution, 1974 b, 31, and Human $12 \mathrm{f}$. 
Laoust, H., $1971 a$, Ibn 'Abd al-Wahhāb. EI 3.

- $1971 b$, Ibn Taymiyya. EI 3.

Revolution, 1973, The Revolution of 1st September, the Fourth Anniversary. Benghazi.

- 1974 a, Ist September Revolution Achievements, 5th Anniversary. Tripoli.

- 1974b, The Popular Revolution, Fundamentals \& Objectives. Tripoli.

- 1974 c, La Revolution en Marche. Tripoli (?).

Séminaire, 1976, Séminaire du dialogue Islamo-Chrétien, Tripoli 1-6 Safar 1396/1-6 Février 1976. Recommandations et résolutions. Tripoli.

at-taharruk, 1976, at-taharruk as-siyāsì lì-l-djumhūriyyat al-'arabiyyat al-lībiyya fí ittidjāh 'așr al-djamāhīr. Tripoli.

Watt, W., 1956, Muhammad at Medina. Oxford.

- 1961, Islam and the Integration of Society. London. 